DOI 10.15826/qr.2017.3.252

УДК 22-288.2+27-36

\title{
THE ANGELOLOGY OF THE EXPLANATORY PALAEA AND THE PROBLEM OF THEODICY ${ }^{\star} \star \star *$
}

\author{
Irina Dergacheva \\ Moscow State University of Psychology and Education, \\ Moscow, Russia
}

The Explanatory Palaea (Rus. Tolkovaya Paleya) is now known to us in the form of over 15 texts dating back to between the $14^{\text {th }}$ and the $17^{\text {th }}$ centuries. It provides a full description of cosmogenesis, the creation of Adam, the structure of the human body, the interaction between soul and body, and the forms of spiritual substances. It also contains natural scientific representations of physical phenomena. Together with the explanation of ontological problems, it describes the structure of the universe, the earth, and the next world. Like the Biblical books of the Old and New Testament, the Explanatory Palaea establishes the principal worldview to be found in medieval Russian texts. The descriptions in it are accompanied by polemics and invectives against the Jews, who refused to accept the main principles of Christian doctrine, pagans, and Muslims. The aforementioned makes it possible to view the Explanatory Palaea as a historic ancient Russian manuscript, truly outstanding due to its absolutely unique worldview and its incomparable religious, philosophi$\mathrm{cal}$, and scientific content. Of special interest is the depiction of the disruption of noumenal beings and the emergence of the binary opposition between good and evil as a result of the fall of the archistrategos of the tenth angelic order. The Genesis catastrophe results in the emergence of evil, a phenomenon originally not included in the divine conception of the creation of the world.

Keywords: Tolkovaya Palaea; theodicy; angelology; hermeneutics; cosmology; exegesis.

Толковая Палея дошла до нас более чем в 15 списках XIV-XVII вв. В ней подробно описаны космогенез, сотворение Адама и устройство человеческого организма, взаимодействие души и тела, формы духов-

* This article was prepared with the financial support of the Russian Humanities Foundation (RHF). Project № 16-04-00523.

** Citation: Dergacheva, I. (2017). The Angelology of the Explanatory Palaea and the Problem of Theodicy. In Quaestio Rossica, Vol. 5, № 3, p. 826-837. DOI 10.15826/ qr.2017.3.252.

Цитирование: Dergacheva I. The Angelology of the Explanatory Palaea and the Problem of Theodicy // Quaestio Rossica. Vol. 5. 2017. № 3. P. 826-837. DOI 10.15826/ qr.2017.3.252.

(C) Dergacheva I., 2017

Quaestio Rossica • Vol. 5 • 2017 • № 3, p. 826-837 
ных сущностей, даны естественнонаучные трактовки физических явлений. Наряду с толкованием онтологических проблем, описаны устройство вселенной, устроение земли и топосы иного мира. Как и библейские книги Ветхого и Нового Заветов, Палея считается произведением мировоззренчески установочным и ключевым в иерархии памятников средневековой русской письменности. Описательные моменты сопровождаются в памятнике полемическими толкованиями и инвективами против иудеев, не принявших основные положения доктрины христианства, а также полемическими выпадами против язычников и магометан. Все это позволяет рассматривать Толковую Палею как памятник древнерусской мысли, который со стороны его идейно-мировоззренческого, религиозно-философского и естественнонаучного содержания имеет совершенно особое значение среди памятников письменности Древней Руси. Особый интерес представляет изображение раскола ноуменальных сущностей и появление бинарных оппозиций добра и зла в результате падения Архистратига десятого ангельского чина. Результатом бытийственной катастрофы становится появление зла как явления, не заложенного в Божественную концепцию творения мира.

Ключевые слова: Толковая Палея; теодицея; ангелология; герменевтика; космология; экзегеза.

The Explanatory Palaea is an incredibly sophisticated compilation of all sources known in medieval Rus. The doctrine of the angelic orders described in the Palaea is based on the Old and New Testaments, as well as the exegesis of the Church Fathers who conceptualised and developed these beliefs.

In the books of the Old and New Testaments, the word 'angel' occurs 348 times in various forms [Симфония для Библии]. In particular, there are many descriptions of angels appearing to the righteous in the Old Testament, for through them the Lord reveals His existence and declares His will to the first Christians. Dionysius the Areopagite emphasises that:

...Закон... был дал нам через ангелов... И славных наших отцов, [живших] до закона и после [того], как был дан закон, возводили к Божеству ангелы, или научая, что должно делать и проводя к прямому пути истины от прелести и жизни нечестивой, или истолковательно открывая священные чины, или сокровенные видения надмирных тайн, или некие Божественные предсказания [Макаров, Мильков, Смирнова, с. 242-243].

(...The law... was given to us by angels... And our glorious fathers, [who lived] before the law, and after the law was given, were sent up to God by angels, who either taught them what is supposed to be done and led them to the right path of truth from the delights and wicked life, or explained [to them] sacred orders, secret visions of transcendent mysteries, or certain divine predictions.) 
Angels appear in key events in worldly history. They serve God, singing a chant (Seraphims in Isaiah $6: 3$ ); they are present before God when He declares His will (Job $1: 6$ ); they appear at God's command to help a man (Isaiah $6: 7$ ) or to punish one (2 Sam $24: 16$ ); and they announce the people's future destiny (Dan $8: 16-26$ ) and deliver their prayers to God (Tob 12:12; Rev $5: 8 ; 8: 3$ ). The appearance of angels accompanies many events in the Gospels: Archangel Gabriel sends the good news to Zechariah and the Virgin Mary (Luke 1:19;26); angels glorify the Nativity (Luke 2 : 9-14); they help the Saviour in his agony at Gethsemane (Luke 22: 43); they proclaim His Resurrection (Matt $28: 5-7$ ); and they explain the meaning of the Ascension of Christ to the apostles (acts $1: 10-11$ ):

Сам Иисус, надсущностная Причина наднебесных сущностей... благопокорно повинуется указаниям Отца и Бога, [даваемым] через ангелов [Палея Толковая, с. 245].

(Jesus himself, the superior Cause for all heavenly hosts... humbly obeys the commands of the Father and God [given] through angels.)

In particular, much is said about the role of angels in the fate of the world and humanity in the Apocalypse. Led by Archistrategos Michael, they have been fighting the battle against Satan from the beginning of time and will accompany Christ during His Second Coming.

The Palaea begins with a story about creation of the world: this contains extensive interpretations borrowed from the works of Severian of Gabala and Basil the Great, St John Chrysostom's interpretation of the Book of Genesis, Epiphanius of Cyprus' writings, and John the Exarch's Hexaemeron. Here, the appearance of angels precedes the creation of the earthly world:

Превечный Бог, безначальный и бесконечный, будучи Богом сил, сначала сотворил огненных духов - своими ангелами и слугами, - как о том божественный Давид писал в 103-м псалме. Всего Бог сотворил 10 чинов: первый чин - ангелы, второй чин - архангелы, третий чин - начала, четвертый - власти, пятый - силы, шестой - престолы, седьмой - господства, восьмой - многоокие херувимы, девятый чин - шестикрылые серафимы; к десятому чину [относились] те, кто превратился в демонов [Там же, с. 13].

(The pre-eternal God, beginningless and endless, being God of heavenly hosts, first created the fire spirits to be his angels and servants, - the divine David wrote in Psalm 103. In total, God created 10 orders: the first one - angels, the second - archangels, the third - principalities, the fourth-powers, the fifthvirtues, the sixth - thrones, the seventh - dominions, the eighth - many-eyed cherubim, the ninth - six-winged seraphim; and those who turned into demons [belonged] to the tenth order.) 
Next, the Lord built a hierarchy: «Над всеми силами каждого чина Господь Бог поставил старшин, воевод и начальников чинов» (Over all the hosts of each order, the Lord set elders, commanders and order chiefs) [Там же].

Here, the connection between the two worlds - the noumenal and the material - is the unity of two structures, spirit and matter. The metaphysical space is placed above the material space of phenomena.

After describing the creation of angels, the author of the Palaea asks:

Отчего Моисей не начал описывать [творение] с ангелов, но, не упомянув ни словом о множестве вышних сил, начинает с неба и земли? [Там же].

(Why did Moses not begin the description [of creation] from angels but from heaven and earth, without mentioning the numerous higher forces?)

Why does he tell us that «В начале сотворил Бог небо и землю» (In the beginning God created the heaven and the earth) (Genesis 1:1). After asking the question, the author of the Palaea answers it himself:

Божественный Моисей, оставив все вышнее, немедленно приступил к описанию [творения неба и земли], дабы сыны израильские оставили египетское безбожие', ибо уши их полны египетских соблазнов [Там же, с. 14].

(The divine Moses, having put away everything that was higher, immediately proceeded to the description [of the creation of heaven and earth] so that the children of Israel would leave Egyptian miscreance, because their ears were full of the temptations of Egypt).

The primacy of the creation of the invisible world has been a subject of theological disputes for centuries. However, this opinion, shared by the author of the Palaea, became the most common one among the Fathers of the Church and was included in the catechisms and manuals of dogmatic theology. It was supported by Basil the Great, Gregory the Theologian, John Chrysostom, Ambrose of Milan, Anastasius the Sinaite, and others.

In the first homily of the Hexaemeron, Basil the Great wrote the following on the creation of the world of the highest spirit:

Еще ранее бытия мира было некоторое состояние, соответствующее премирным силам, превысшее времени, вечное, всегда продолжающееся. В нем-то Творец и Зиждитель всяческих совершил создания - мысленный свет, приличный блаженству любящих Господа, разумные и невидимые природы и все украшение умосозерцаемых тварей, превосходящих наше разумение, так что нельзя изобрести для них и наименований. Они-то наполняют собою сущность невидимого мира, как научает нас Павел, говоря: 
ибо Им создано все... видимое и невидимое: Престолы ли, Господства ли, Начальства ли, Власти ли (Кол $1: 16$ ), и ангельские воинства, и архангельские чиноначалия [Творения иже во святых отца нашего Василия Великого].

(The birth of the world was preceded by a condition of things suitable for the exercise of supernatural powers, outstripping the limits of time, eternal and infinite. The Creator and Demiurge of the universe perfected His works in it, spiritual light for the happiness of all who love the Lord, intellectual and invisible natures, all the orderly arrangement of pure intelligences who are beyond the reach of our mind and of whom we cannot even discover the names. They fill the essence of this invisible world, as Paul teaches us: "For by Him were all things created that are in heaven, and that are in earth, visible and invisible whether they be thrones or dominions or principalities or powers" (Col 1:16) or virtues or hosts of angels or the dignities of archangels.)

Gregory the Theologian expressed it similarly: «...прежде всего Он вымышляет ангельские и небесные силы» (...God created first of all the angelic heavenly powers). His opinion was shared by John of Damascus:

Я же соглашаюсь с Богословом. Ибо надлежало, чтоб прежде всего была создана постигаемая только умом сущность [Св. Иоанн Дамаскин, с. 121].

(For myself, I am in harmony with the Theologian. For it was fitting that the mental essence should be the first created.)

Jerome, John Chrysostom, and Ambrose of Milan all agreed with them:

К заключению о том, что ангелы могли быть сотворены прежде всякой материальности, подводит книга Иова, в которой говорилось, что творение в первый день мироздания осуществлялось Богом при общем радостном ликовании «сынов Божиих» (Иов. 38 : 4-7) [Там же, с. 529].

(The Book of Job allows us to conclude that the angels could be created before any materiality. The Book of Job states that the creation on the first day of creation was performed by God with a cheerful rejoicing of "sons of God".)

However, one also finds other ideas in the exegetical literature. In the apocryphal Book of Jubilees from the Old Testament, the act of the creation of the angels is simultaneous with the creation of heaven and the elements:

Ибо в первый день Он сотворил небеса, которые вверху, и землю, и воды, и всех духов, которые Ему служат, и Ангелов лица, и Ангелов прославления, и Ангелов духа огня, и Ангелов духа ветров, и Ангелов облачных духов мрака, и града и инея, и Ангелов долин, и громов и мол- 
ний, и Ангелов духов холода и зноя, зимы и весны, осени и лета, и Ангелов всех духов Его творений на небе, и на земле, и во всех долинах, и духов мрака и света, и утренней зари, и вечера, которые Он приготовил по предвидению Своей премудрости [Книга Юбилеев].

(For on the first day He created the heavens which are above and the earth and the waters and all the spirits which serve before Him - the angels of the presence, and the angels of sanctification, and the angels [of the spirit of fire and the angels] of the spirit of winds, and the angels of the spirit of clouds, and of darkness, and of snow and of hail and of frost, and the angels of the valleys and of the thunder and of the lightning, and the angels of the spirits of cold and of heat, and of winter and of spring, and of autumn and of summer, and of all the spirits of his creatures which are in the heavens and on the earth, (He created) the abysses and the darkness, eventide [and night], and the light, dawn and day, which He hath prepared in the knowledge of his heart.)

V. V. Milkov notes that 'this view is further consistently reproduced by the author of the Palaea, who relied on Epiphanius of Cyprus and Antiochian sources of the compilation which preserved the Old Testament apocryphal interpretation. But all the arguments stating that the angels of the elements occur together with the elements disagree with the earlier statement on the primary creation of angels. This unresolved contradiction is probably related to the character of the compilation of the work. Generally, the angelology of the Palaea dates back to the Old Testament apocryphal tradition, which had developed the motifs of the Book of Jubilees and associated the appearance of spiritual essences with the first day of creation' [Палея Толковая, с. 529].

Indeed, as soon as the author of the Palaea begins to describe in detail the duties of the angels, he definitely associates their appearance with the first day of creation:

[Ангелы же] суть служебные духи, посылаемые на службу: ангелы облаков, ангелы тумана, ангелы града, ангелы льда, ангелы туч, ангелы изморози, ангелы инея, ангелы мороза, ангелы росы, ангелы звуков, ангелы молнии, ангелы грома, ангелы зноя, зимы и лета, весны и осени - словом, всех созданий Его. Все эти дела (вещи), неизреченные, непостижимые и недоступные уму, Владыка Господь Бог в первый день своею мудростью сотворил [Там же, с. 17].

([The angels] are ministering spirits sent out to serve: the angels of clouds, the angels of mist, the angels of hail, the angels of ice, the angels of thunderclouds, the angels of frost, the angels of hoar, the angels of frost, the angels of dew, the angels of voices, the angels of lightning, the angels of thunder, the angels of heat, of winter and summer, spring and autumn, and, in a word, of all His creatures. All these things and deeds, indescribable, incomprehensible, unconceivable, the Lord has prepared in the first day in the knowledge of his heart.) 
The text of the Palaea is riddled with apocryphal allusions and is intertextual. The author, a brilliant exegetical scholar when analysing the Scriptures on topics that interest him, complements their content with texts he learned from apocryphal books. For example, when referring to the description of the angelic ministry by St Paul from the books of the New Testament, he complements them with information about St Paul's ascent into heaven from the apocryphal Vision of St Paul [Мильков]:

И в Послании коринфянам апостол Павел сказал: «Не подобает мне хвалиться, ибо я приду в видении явления Господня. Знаю человека во Христе, который 14 лет тому назад (или в теле, или вне тела, не знаю, Бог ведает) восхищен был до третьего неба и слышал неизреченные слова, которых человеку нельзя пересказать, и был перенесен в рай» (2 Кор. 12 : 1-4) [Палея Толковая, с. 33-34].

(And in Corinthians the Apostle Paul said, "It is doubtless not profitable for me to boast. I will come to visions and revelations of the Lord: I know a man in Christ who fourteen years ago- whether in the body I do not know, or whether out of the body I do not know, God knows - such a one was caught up to the third heaven. And I know such a man - whether in the body, or out of the body I do not know, God knows - how he was caught up into paradise and heard inexpressible words, which is not lawful for a man to utter".)

One can find the most detailed teaching about angels in the exegetical interpretation of the Scriptures from Dionysius the Areopagite's book On the Celestial Hierarchy. Nine orders are divided into three hierarchies: the first are thrones, cherubims, and seraphims; the second are dominions, virtues, and powers; and the third - principalities, archangels, and angels. This detailed description of the 'angelic order' is supplemented by the explanation of the origin of the names of angels, their numerology (Chapter 14. What does the number of angels given [to us] in the Scriptures mean? [Там же, c. 276]), and their images (Chapter 15. What are the images of the angelic forces: what is firelikeness or humanlikeness, what are eyes, hands, ears, nostrils and so on [Там же, c. 277]). A description of the hierarchy of the angelic forces is given in detail in the apocryphal 'Testament of Adam' [Порфирьев, с. 172-173].

The noumenal nature of angels is described in philosophical terms by A. P. Shcheglov: "The angels per se are builders of space-time constraints, and not the very substance of matter and form. What is inherent in the ultimate ontological grounds belongs to the Supreme Being and not to immanent phenomena. Creations, even those at the highest level of creation, cannot know the Absolute, much less create something infinite. Angels in the old Russian view are a multiple vovc, i. e. a mind-managing fixed substance" [Щеглов, 2007, с. 21].

The sequence between the first and second hierarchies is broken in the Palaea, as dominions and thrones, listed one after another, should be placed in the reverse order. Shcheglov drew attention to the fact that 
the order of the angelic hierarchy goes not from top to bottom, but marks the ascent from the 'earthly to the heavenly'. As a consequence, the hierarchical structure of the world order is the reverse of that offered by authoritative theological opinion [Щеглов, 1988, с. 227].

The description of the angels emphasises their strength of mind, freedom of will, incorporealness (although in the material world they have the ability to temporarily obtain a body), existence beyond any dimensions (an angel, being merely a mind, does not occupy space), and infinity of existence. They do not possess verbal speech, but communicate among themselves via thought:

Ангелам по природе [свойственно] понимать смысл слов безмолвно и сноситься друг с другом только мысленно [Палея Толковая, с. 13].

(The angels [inherently] understand the meaning of words silently and communicate with each other only mentally.)

Sometimes angels are permitted to foresee the future:

Того же, что должно быть, не ведают ни ангелы, ни падшие с небес. Если же будущее бывает открыто, то посланными от Бога ангелами, который велит им провозвестить Его своим угодникам. И то, что говорят ангелы, [действительно] сбывается [Там же, с. 59].

(Those things that must be neither the angels nor those fallen from heaven know. If the future is disclosed, it is disclosed by the angels sent from God, Who tells them to announce it to His saints. And what the angels tell [really] comes to be true.)

The Palaea constantly emphasises the fact that the angels are 'ministering spirits who are sent forth to minister' (Heb. 1:14). The Scriptures say: «звездам и обоим светилам совершать движение по воздуху при помощи разумных сил» (the stars and the two great lights are to move in the air with the help of intelligent force) [Там же, с. 33]. However, the ministering function of angels has its limits in time:

В конце веков ангелы освободятся от обязанностей своей службы, которую они исполняют ради человека. О конце века сказал в Евангелии Сам Бог: «Ибо тогда силы небесные поколеблются, и звезды, словно листья, спадут с неба на землю» (Мф. 24 : 29-30). Небесными силами Он называет ангелов; падение звезд на землю произойдет из-за освобождения ангелов от своей службы управления звездами [Там же, с. 33].

(Immediately after the tribulation of those days the angels will be free of the service that they perform for mankind. God himself spoke of the end of times in the Gospel: "For then the powers of heaven shall be shaken, and the stars, like 
leaves, shall fall from heaven to earth" (Matt. 24 : 29-30). The powers of heaven are what he calls angels; the stars shall fall to earth due to the release of the angels from their service of star maintenance.)

However, long before the apocalyptic transformation of the earth, the divine harmony was broken by the distortion of the essence of one of the angels of the tenth angelic order, resulting in the split of the noumenal world:

В этот день [творения] один из ангелов по имени Сатана, который был старейшиной десятого чина, увидел, как Бог украсил ту твердь, о которой мы говорили, то есть небо и землю, преисполнился гордыней и подумал: «Как прекрасна вселенная, но не вижу на ней жителей; приду на землю и возьму ее и буду обладать ею и буду как Бог, и поставлю престол свой на облаках». И тотчас сверг его Господь с небес за гордость помысла его [Там же, с. 57].

(On that day [of creation], one of the angels named Satan, who was the elder of the tenth order, saw how God had adorned the firmament which we talked about, that is, the heaven and the earth, and became filled with pride, and thought: "How beautiful the universe is, but I do not see residents there. I shall come to earth and take it and possess it, and be like God, and I shall set my throne on the clouds." And the Lord immediately cast him down from heaven for the pride of his thought.)

The subordinates of the archistrategos were also punished: they were scattered all over the underworld, cast down to the earth, or suspended in the air:

Вслед за ним, словно песок, просыпавшийся с небес, пал подначальный ему десятый чин: одни пролетели в преисподнюю, другие пали на землю, третьи повисли в воздухе [Там же].

(After him, like sand spilled from heaven, the tenth order, subordinate to him, also fell: some flew into the underworld, others fell to earth or were suspended in the air.) [Там же].

From this point, the existential opposition of good and evil has permeated the noumenal and material worlds.

Archistrategos Michael, the commander of the army of the Lord and elder of the secondorder, explains the essence of the universal tragedy: «Внемлем, ибо с нами свет, и ныне, обличенные светом, вы стали тьмой!» (We listen, for we are the light, and now, exposed by the light, you have become the darkness!) [Там же, с. 58]. Thus, angels, entities of the noumenal world, turn into their opposite, i. e., devils. The author of the Palaea thoroughly describes their fate: 
И бесы, слышавшие глас архангела Михаила, тут же были повешены в воздухе. Первые же падшие бесы, которые провалились в преисподнюю, теперь как глухие и с тех пор ничего в мире не знают. А те из них, которые пали на землю, те ходят по земле, причиняя зло своими соблазнами. Последние же из них архангельским гласом оставлены в воздухе, и они, повиснув, творят пакостей сколько могут [Там же].

(And the devils who heard the voice of the Archangel Michael were immediately suspended in the air. The first fallen devils that fell into the underworld are now like the deaf and since then they have known nothing in the world. And those of them who fell to earth are walking over the earth, causing evil by their temptations. The last of them are left in the air by the Archangel's voice and they, having been suspended, do as much mischief as they can.)

The new commander of the demons, «Сатана, бывший старейшиной в чине, стал начальником земного чина [бесов] и получил власть над землей» (Satan, a former elder in the order, became commander of the earthly order [of demons] and got the power over the earth) [Там же].

The Palaea describes the sorcery of the demons in detail:

То же, что бесы «пророчествуют» волшебникам, чародеям, колдунам и прорицателям, то не все прямо сбывается. Иногда они знают, что случится в далеком будущем, и иной раз, по промыслу, об этом говорят. Иногда же они обвораживают маловеров и, увлекая их к погибели, смущают их кознями и соблазнами, обольщают ложью их ум. Даже если иногда они говорят истину, то итог их слов все равно ведет к злу, заставляя лгать. Потому не следует им верить, ибо очевидно, что после падения бесам уже нет покаяния, как и людям после смерти [Там же, с. 59].

(Not everything that the demons prophesise to magicians, enchanters, sorcerers, and soothsayers is to come true. Sometimes they know what will happen in the distant future, and now and then, by Providence, they talk about this. But sometimes they bewitch those of little faith and, dragging them to perdition, confuse them by wiles and temptations, deceiving their mind with lies. Even if sometimes they speak the truth, ultimately their words still lead to evil, making people lie. That is why one should not believe them, for it is evident that after the fall, the devils have no repentance, like people have none after death.)

The invectives against witchcraft in the Tale of the Past Years may have been borrowed from this particular source: 'In the ridicule of the sorcery common among the pagans, the author (of the Tale of the Past Years. I. D.) shows extraordinary erudition. He brings up the story from the times of the Greek king Domitian about the magician Apollonius of Tyana, who performed demonic miracles everywhere from Rome to Byzantium. Although he had some success in these miracles, expelling numerous snakes 
and scorpions from cities, calming horses' rage, and exterminating gnats in Antioch, all of this was done with demonic force. The demons helped the magician in his sorcery not only during his life: they also possessed his soul after death. Even at the tomb of the magician, demons, wearing his face and name, continued to deceive gullible people' [Дергачева, c. 98].

Since the fallen angels turned into demons of darkness, existence has been influenced by opposed noumenal powers. The angelic world remains unchanged, but a tenth of its noumenal space has defected from it, i. e., the archistrategos of the tenth angelic order (Lucifer and his angels who were turned into demons). Since the earth, or rather the part of it known as the underworld, became their place of residence, a modern cosmic setup was established, presented via a binary opposition: heaven, a noumenal sphere for the original angelic entities, is opposed to the earth, which is vulnerable to Lucifer and the evil and corruption brought by his armies. This opposition, which permeates medieval cosmology, is related to the advent of evil. The topoi are localised: earth vs. heaven, heaven vs. hell, life vs. death, eternity vs. finiteness, good vs. evil, spirit vs. matter, and right vs. left. The world is dichotomous: there is heaven, where the souls of the righteous go, and hell, where sinners languish, and between lies a material world, i. e., the earth.

Thus, the text of the Palaea confirms ideas characteristic of medieval Russian philosophy: that evil had no original existence, that it is finite, and that it was not a part of the Divine plan of creation. The energy of Lucifer and his demons is an emanation of evil; everything that they touch becomes mortal and finite, they corrupt everything, including themselves, and are approaching their own destruction. However, at the moment when the universe is transfigured into the New Jerusalem, when 'heaven and earth reunite' at the end of times, Lucifer will cease to exist, and with that evil will disappear from the world.

\section{Список литературы}

Дергачева И. В. Посмертная судьба и «иной мир» в древнерусской книжности. М. : Кругъ, 2014. 352 с.

Иоанн Дамаскин, св. Точное изложение православной веры: творение св. отца нашего Иоанна Дамаскина [репринт. изд.]. М. : Братство свт. Алексия ; Ростов н/Д : Приазов. край, 1992. 464 с.

Книга Юбилеев, или Малое Бытие. 2-й вып. Ветхозаветных апокрифов / [Соч.] доц., акад. свящ. А. Смирнова. Казань : Типолит. ун-та, 1895. 2008 c. URL: http://royallib.com/read/avtor_neizvesten/kniga_yubileev.html\#0 (дата обращения: 12.11.2016).

Макаров А. И., Мильков В. В., Смирнова А. А. Древнерусские Ареопагитики // Памятники древнерусской мысли: исследования и тексты. Вып. 3 (1). М. : Кругъ, 2002. $589 \mathrm{c}$.

Мильков В. В. Видение апостола Павла // Древнерусские апокрифы. СПб. : РХГИ, 1999. C. 528-581.

Палея Толковая / науч. ред. А. Н. Камчатнов. М. : Согласие, 2012. 651 с.

Порфирьев И. Апокрифические сказания о ветхозаветных лицах и событиях. Казань : Университет. тип., 1872. 309 с. 
Симфония для Библии // Библия-онлайн [сайт]. URL: http://bible.by/symphony/ letter/1/ (дата обращения: 18.11.2016).

Творения иже во святых отца нашего Василия Великаго, Архиепископа Кесарии Каппадокийския : в 3 ч. 3-е изд. М. : Тип. М. Г. Волчанинова, 1891. Ч. 1. 332 с.

Толковый словарь русского языка с включением сведений о происхождении слов / отв. ред. Н. Ю. Шведова. М. : Азбуковник, 2008. 956 с.

Щеглов А. П. Философские аспекты древнерусских представлений о природе зла // Изв. Рос. гос. пед. ун-та им. А. И. Герцена. Вып. 47. Т. 9. СПб. : РГПУ им. А. И. Герцена, 2007. С. 14-26.

Щеглов А. П. Комментарии к Толковой Палее // Волшебная гора. Вып. 7. М. : Волшебная гора, 1988. С. 223-240.

\section{References}

Dergacheva, I. V. (2014). Posmertnaya sud'ba i "inoj mir" $v$ drevnerusskoj knizhnosti [Life after Death and the Next World in Old Russian Literature]. Moscow, Krug. 352 p.

Kniga Yubileev, ili Maloe Byitie. 2 vyip. Vethozavetnyih apokrifov [The Book of Anniversaries, or Small Existence. $2^{\text {nd }}$ Ed. of Old Testament Apocrypha] [Soch.] (1895) dots., akad. svyasch. A. Smirnova. Kazan : Tipolitographija Universiteta. URL: http:// royallib.com/read/avtor neizvesten/kniga yubileev.html\#0 (mode of access: 12.11.2016).

Makarov, A. I., Mil'kov, V. V., Smirnova, A. A. (2002). Drevnerusskie Areopagitiki [Medieval Russian Areopagitica]. In Pamyatniki drevnerusskoj mysli: issledovaniya $i$ teksty. Vol. 3 (1). Moscow, Krug. 589 p.

Mil'kov, V. V. (1999). Videnie apostola Pavla [Vision of Apostle Paul]. In Drevnerusskie apokrify. St Petersburg, RHGI, pp. 528-581.

Kamchatov, A. N. (Ed.). (2012). Palaea Tolkovaya [Explanatory Palaea]. Moscow, Soglasie. $651 \mathrm{p}$.

Porfir'ev, I. Ya. (1872). Apokrificheskie skazaniya o vethozavetnyh licah i sobytiyah [Apocryphal Stories about Old Testament Persons and Events]. Kazan, Universitetskaya tipographija. $309 \mathrm{p}$.

John of Damascus, St. (1992). Tochnoe izlozhenie pravoslavnoj very [Exposition of the Orthodox Faith]. 464 p. Moscow, Bratstvo svt. Aleksiya; Rostov-on-Don, Priazovski krai.

Simfoniya dlya Biblii [A Symphony for the Bible]. URL: http://bible.by/symphony/ letter/1 (mode of access: 18.11.2016).

Tvoreniya izhe vo svyatyih ottsa nashego Vasiliya Velikago, Arhiepiskopa Kesarii Kappadokiyskiya [Works by Our Holy Father Saint Basil the Great, Archbishop of Caesarea of Cappadocia]. (1891). Part 1. $3^{\text {rd }}$ Ed. Moscow, Tipographija M. G. Volchaninova.

Shvedova, N. Yu. (Ed.). (2008). Tolkovyj slovar' russkogo yazyka s vklyucheniem svedenij o proiskhozhdenii slov [Explanatory Dictionary of the Russian Language with Etymological Evidence]. Moscow, Azbukovnik. 956 p.

Shcheglov, A. P. (2007). Filosofskie aspekty drevnerusskih predstavlenij o prirode zla [Philosophical Aspects of the Mediaeval Russian Idea of the Nature of Evil]. In Bazhov, S. I., Blauberg I. I. (Ed.) Izvestiya Rossijskogo gosudarstvennogo pedagogicheskogo universiteta im. A.I. Gercena. Iss. 47. Vol. 9. St Petersburg, RGPU Im. Gerzena, pp. 14-26.

Shcheglov, A. P. (1988) Kommentarii k Tolkovoj Palee [Commentary to the Explanatory Palaea]. In Volshebnaya gora, Vol. 7. Moscow, Volshebnaya gora, pp. 223-240. 